\title{
Studi Keterampilan Metakognitif pada Siswa Sekolah Menengah Atas Negeri (SMAN) 1 Margaasih Kabupaten Bandung
}

\author{
Ecep Supriatna ${ }^{1 *}$, Tuti Alawiyah ${ }^{2}$ \\ ${ }^{12}$ Program Studi Bimbingan dan Konseling, Fakultas Ilmu Pendidikan, IKIP Siliwangi-Cimahi \\ *Email: Ecep83supriatna@gmail.com
}

\begin{abstract}
ABSTRAK
Penelitian ini bertujuan menganalisis tingkat keterampilan metakognitif siswa (SMAN) 1 Margaasih Kabupaten Bandung Propinsi Jawa Barat. Penelitian ini merupakan studi deskriptif dengan melibatkan 356 siswa sebagai partisipan yang terdiri 160 siswa laki-laki dan 196 siswa perempuan dari kelas X, XI, dan XII. Data dijaring dari dua instrument penelitian yaitu formulir informasi pribadi (Personal Information Form) yang dikembangkan oleh peneliti untuk menjaring data yang berkaitan dengan tingkat kelas dan jenis kelamin serta Skala Keterampilan Metakognitif (Metacognitif Skills Scale) yang diadaptasi dari Tuncer and Kaysi (2013). Temuan penelitian menunjukan bahwa siswa memiliki keterampilan metakognitif yang tinggi yang terdiri dari tiga aspek yaitu keterampilan berpikir reflektif untuk menyelesaikan masalah, keterampilan membuat keputusan dan keterampilan membuat evaluasi alternatif. Hasil keterampilan metakognitif berdasarkan level kelas menunjukan bahwa keterampilan metakognitif siswa meningkat seiring dengan meningkatnya level kelas. Dari aspek gender, hasil penelitian menunjukan bahwa siswa laki-laki dan siswa perempuan memeiliki tingkat keterampilan metakognitif yang relatif sama.
\end{abstract}

Kata Kunci : Keterampilan Metakognitif, SMAN 1 Margaasih, Kabupaten Bandung

\begin{abstract}
This study aims to investigate the level of student's metacognitive skills at Public Senior High School (SMAN) 1 Margaasih Bandung. This research is a descriptive study which involved 356 Senior High Students as participants consits of 160 male students and 196 female students. They are the 10th, 11th, and 12th graders. The data were collected from Personal Information Form to know the students' grade and gender, and scale of metacognitive skills adapted from Tuncer and Kaysi (2013) to assess students' metacognitive skills. The findings indicate that Senior High Students have high metacognitive skills which consist of three sub-dimensions namely reflective thinking skills to solve problems, skills to make decision and skill to make alteternative evaluation. In addition, the result of student's metacognitive skills in term of class level indicate that the student's metacognitive skills tend to increase as students get higher level. In term of gender, the result shows that both male and female students show no significant difference in their metacognitive skills.
\end{abstract}

Keywords : Metacognitive skills, SMAN 1 Margaasih, Bandung District

Diterima: September 2019. Disetujui: November 2019. Dipublikasikan: Desember 2019 457 
Supriatna, E., \& Alawiyah, T

\section{PENDAHULUAN}

Konsep Metakognisi (metacognition) yang pada awalnya dikembangkan dalam bidang penelitian perkembangan (developmental research), pada perkembangan selanjutnya digunakan secara luas dalam penelitian psikologi (Schneider, 2008). Metakognisi merujuk pada keterampilan seseorang dalam memproses informasi serta strategi dalam memproses informasi tersebut. Secara sederhana Flavel (1979) mendefinisikannya sebagai berpikir tentang cara berpikir (thinking about thinking). Sementara Ozsoy \& Ataman (2009: 68) mendefinisikan metakognisi sebagai sebuah bentuk kesadaran dari seseorang terhadap proses berpikirnya sendiri yang dibarengi dengan controlling ability terhadap proses tersebut.

Dalam implementasinya, metakognisi tidak sesederhana definisinya karena merujuk pada sebuah proses mental tingkat tinggi seperti membuat perencanaan, menggunakan strategi yang tepat untuk menyelesaikan sebuah masalah, dan membuat alternatif evaluasi (Dunslosky and Thiede, 1998). Ketiga keterampilan tersebut ditandai dengan kemampuan memilih dan menggunakan strategi belajar secara sadar, efektif dan spontan (Ormord, 2008).

Dalam konteks proses belajar, keterampilan metakognitif merujuk pada kemampuan untuk melakukan refleksi, mengontrol proses berpikir, dan memahami yang pada akhirnya akan berimplikasi pada kemampuan mengendalikan perilaku belajar (Schraw \& Dennison (1994: 460). Secara lebih mendetail dapat dijelaskan bahwa keterampilan metakognitif dalam proses belajar ditandai oleh kemampuan seseorang untuk membuat perencanaan berkaitan dengan apa yang akan dilakukan, memonitor kemajuan dalam belajar, dan melakukan evaluasi hasil belajar.

Penelitian tentang keterampilan metakogntif siswa telah banyak dilakukan bahkan sejak tingkat pendidikan sekolah dasar seperti penelitian yang dilakukan oleh Rukminingrum, Hanurawan, Mudiono (2017) yang menemukan bahwa pengetahuan metakognitif siswa kelas V SDN Pagergunung 03 cukup baik dan mengalami perkembangan seiring dengan berkembangnya usia dan pengetahuan siswa. Penelitian Kusuma \& Nisa (2018), hasil penelitian menunjukkan bahwa ada hubungan yang signifikan antara keterampilan metakognitif dan hasil belajar kognitif mahasiswa program studi S1 PGSD pada perkuliahan Penelitian Tindakan Kelas (PTK) dengan koefisien korelasi sebesar 0.900 (sangat tinggi). Penelitian Budiati, Sugiyarto \& Sarwanto (2012), penelitian menganalisis pola pembelajaran dengan metode POE (Prediction, Observation dan Explanation) ditinjau dari keterampilan metakognitif. Hasil penelitian menunjukkan bahwa tidak ada pengaruh keterampilan metakognitif tinggi dan rendah terhadap keterampilan proses sains, tidak ada pengaruh interaksi antara keterampilan metakognitif dan gaya belajar terhadap keterampilan proses sains, dan interaksi antara model pembelajaran POE menggunakan metode eksperimen terkontrol, keterampilan 
metakognitif tinggi dan gaya belajar visual memberi pengaruh paling baik terhadap keterampilan proses sains.

Penelitian lainnya dilakukan oleh Sugiarto, Prabowo \& Suyono (2012). Penelitian dilakukan bagaimana keterampilan metakognitif digunakan untuk menyelesaikan masalah bentuk molekul dan sudut ikatan. Hasil penelitian menunjukkan bahwa keterampilan metakognitif digunakan dalam tahapan planning, monitoring dan reflection dengan menggunakan teori VSEPR pada pembeajaran biologi. Penelitian Fitrih, Ardiana \& Siregar (2018), hasil penelitian menunjukkan bahwa (1) siswa yang memiliki kemampuan matematika tinggi memiliki pemecahan masalah matematika yang sangat baik (metakognitifstrategic use), (2) siswa yang memiliki kemampuan matematika sedang memiliki pemecahan masalah matematis yang baik (metakognitif aware use), dan (3) siswa yang memiliki kemampuan matematika rendah memiliki cukup pemecahan masalah matematika (metakognitif tacit use). Penelitian Mustaqim, Abdurrahman \& Viyanti (2013) mengenai pengaruh keterampilan metakognitif terhadap motivasi dan hasil belajar dengan metode PBL. Hasil penelitian menunjukkan bahwa terdapat pengaruh keterampilan metakognitif terhadap motivasi belajar sebesar 22\%. Selain itu hasil penelitian menunjukkan terdapat pengaruh keterampilan metakognitif terhadap hasil belajar sebesar $27 \%$.

Konteks penelitian ini berkaitan dengan keterampilan metakognitif siswa pada tingkat pendidikan sekolah menengah atas dianalisis berdasarkan subdimensi dari keterampilan metakognitif itu sendiri, berdasarkan tingkat kelas, dan berdasarkan jenis kelamin. Berdasarkan sub-dimensi keterampilan metakognitif merujuk pada tiga keterampilan, yaitu; (1) kemampuan berpikir reflektif untuk menyelesaikan masalah; (2) kemampuan membuat keputusan; (3) kemampuan membuat alternatif evaluasi. Berdasarkan level kelas dimaksudkan untuk melihat apakah keterampilan metakognitif siswa berkembang seiring dengan meningkatnya level kelas dan usia mereka, sementara berdasarkan jenis kelamin untuk melihat apakah ada perbedaan antara siswa laki-laki dan perempuan dalam keterampilan metakognitif.

Penelitian ini menggunakan metode deskriptif untuk menganalisa tingkat keterampilan metakognitif siswa berdasarkan variabel-variabel keterampilan metakognitif, tingkat kelas, dan perbedaan jender. Penelitian ini melibatkan 356 siswa SMA sebagai partisipan. Data dari partisipan dijaring dengan menggunakan instrumen yang terdiri dari;1) Formulir informasi pribadi (Personal Information Form) yang dikembangkan oleh peneliti untuk menjaring data yang berkaitan dengan tingkat kelas dan jenis kelamin; (2) Skala Keterampilan Metakognitif (Metacognitif Skills Scale) yang diadaptasi dari Tuncer and Kaysi (2013). Skala Keterampilan Metakognitif digunakan untuk mengetahui tingkat keterampilan metakognitif siswa yang meliputi tiga aspek yaitu kemampuan berpikir reflektif untuk 
Supriatna, E., \& Alawiyah, T

menyelesaikan masalah, kemampuan membuat keputusan, dan kemampuan membuat alternatif evaluasi (alternative evaluation ability). Respon dari partisipan diberi skor sebagai berikut; 'sangat setuju' untuk skor ' 5 ', 'setuju' untuk skor '4', 'ragu-ragu' untuk skor ' 3 ', 'tidak setuju' untuk skor '2', dan 'sangat tidak setuju' untuk skor ' 1 '.

Pengolahan data yang terkumpulkan dilakukan secara descriptive statistic untuk mendeskripsikan keterampilan metakognisi berdasarkan rubrik Skala Keterampilan Metakognitif (Metacognitif Skills Scale). Jumlah partisipan, nilai ratarata untuk setiap sub-dimensi keterampilan metakognitif dan standar deviasi dikalkulasi untuk menganalisis tingkat keterampilan metakognitif secara keseluruhan, tingkat keterampilan metakognitif berdasarkan tingkat kelas, dan tingkat keterampilan metakognitif berdasarkan jenis kelamin.

\section{LANDASAN TEORITIS}

Keterampilan metakognitif diyakini menjadi sebuah prediktor kuat (strong predictor) bagi kesuksesan belajar (Dunning, Johnson, Ehrlinger and Kruger, 2003; Kruger and Dunning, 1999). Siswa dengan keterampilan metakognitif yang baik memperlihatkan performa akademik yang lebih baik dibandingkan dengan teman sebayanya dengan keterampilan metakognitif yang kurang (Coutinho, 2007). Ini karena siswa dengan keterampilan metakognitif yang bagus mempunyai kemampuan untuk menjadi lebih strategis dalam proses belajar mereka (Everson and Tobias, 1998). Belajar yang strategis tersebut ditandai oleh beberapa indikator, yaitu; (1) Siswa memiliki keterampilan dalam mengatur diri sendiri (selfdirected) ketika menghadapi tugas-tugas akademik yang beragam; (2) Siswa memiliki keterampilan untuk berorientasi pada tujuan yang ingin dicapai (goalorinted); (3) siswa memiliki keterampilan untuk melakukan evaluasi terhadap proses belajarnya sendiri (self-evaluation).

Selain mendorong siswa untuk memiliki keterampilan belajar reflektif seperti yang diuraikan diatas, keterampilan metakognitif juga dapat mengembangkan beberapa aspek yang lain dari kemampuan siswa, yaitu; (1) mendorong siswa untuk memiliki kemampuan berpikir kritis dan analitis; (2) mendorong siswa untuk belajar lebih mendalam (deep learning) sehingga akan mendapatkan pemahaman yang lebih mendalam (deep understanding) terhadap subjek yang dipelajari; (3) mendorong siswa untuk mempuyai tanggung jawab dalam mengelola kegiatan belajar mereka dimana mereka secara fleksibel dapat mengatur atau mengganti strategi belajar sesuai dengan tuntutan tugas yang mereka hadapi.

Bagi guru, siswa yang memiliki keterampilan metakognitif yang bagus akan mempermudah proses pembelajaran karena siswa dapat dikondisikan untuk berperan secara lebih aktif sehingga kegiatan belajar lebih bersifat student-centered dimana hal ini sesuai dengan teori belajar konstruktivisme dimana peran siswa 
mendapatkan porsi yang lebih banyak dalam proses pembelajaran (Tuncer et al., 2016).

Keterampilan metakognitif siswa tentu saja akan berimplikasi pada pencapaian akademik mereka. Beberapa penelitian menunjukan bahwa siswa dengan keterampilan metakognitif yang baik memperoleh hasil akademik yang lebih bagus dibandingkan mereka dengan keterampilan metakognitif yang kurang baik. Penelitian yang dilakukan oleh Kirkwood (2000) and Leamnson (1999) menunjukan bahwa siswa yang tidak keterampilan metakognitifnya tidak terasah cenderung tidak efektif dalam belajar karena mereka lebih fokus pada nilai bukan pada belajar, cenderung menghapal bukan memahami, dan lebih tergantung pada motivasi eksternal bukan pada motivasi internal. Coutinho (2007) menjelaskan bahwa terdapat hubungan positif antara prestasi belajar dengan metakognitif. Prestasi belajar siswa yang memiliki tingkat metakognitif tinggi akan lebih baik jika dibandingkan dengan siswa yang memiliki tingkat metakognitif rendah.

\section{HASIL DAN PEMBAHASAN}

Berdasarkan hasil olah data, keterampilan metakognitif siswa SMA untuk setiap aspeknya ditampilkan dalam Tabel 1.

Tabel 1.

keterampilan metakognitif siswa SMA berdasarkan aspek keterampilan metakognitif

\begin{tabular}{llll}
\hline Variabel & N & N.Rata2 & SD \\
\hline $\begin{array}{l}\text { Tingkat keterampilan berpikir flektif dalam menyelesaikan } \\
\text { masalah }\end{array}$ & 356 & 15.54 & 3.48 \\
Tingkat keterampilan membuat keputusan & 356 & 18.19 & 12.07 \\
Tingkat Keterampilan membuat evaluasi alternatif & 356 & 21.73 & 2.39 \\
Skala keterampilan metakognitif keseluruhan & 356 & 72.43 & 21.37 \\
\hline
\end{tabular}

Sumber: Observasi Penulis

Sebelum penelitian dilaksanakan, instrumen yang digunakan diuji terlebih dahulu untuk mengetahui validitas dan reliabilitasnya. Sehingga data yang diperoleh valid dan reliabel. Tabel 2. Menunjukan bahwa siswa memperoleh mean 15.54 dan SD 3.48 untuk tingkat keterampilan berpikir reflektif dalam menyelesaikan masalah; 18.19 dan SD 12.07 untuk tingkat keterampilan berpikir dalam membuat keputusan; 21.73 dan SD 2.39 untuk keterampilan membuat evaluasi alternatif; skala keseluruhan untuk keterampilan metakognitif adalah 72.43 dan standar deviasi untuk keterampilan metakognitif adalah 21.37. Dari data diatas tampak bahwa tingkat keterampilan metakognitif siswa adalah tinggi. 
Tabel 2.

Nilai keterampilan berpikir siswa SMA berdasarkan kelas

\begin{tabular}{llll}
\hline Kelas & N & Nilai Rata-rata & Standar Deviasi \\
\hline Kelas X & 120 & 66.96 & 14.29 \\
Kelas XI & 132 & 72.64 & 11.43 \\
Kelas XII & 104 & 76.95 & 10.53 \\
\hline
\end{tabular}

Sumber: Observasi Penulis

Berdasarkan Tabel 3. Tampak bahwa keterampilan metakognitif siswa kelas sepuluh (X) memperoleh nilai mean 66.96 dengan standar deviasi 14.29; siswa kelas sebelas (XI) memperoleh nilai mean 72.64 dengan standar deviasi 11.43; siswa kelas dua belas (XII) memperoleh nilai mean 76. 95 dengan standar deviasi 10.53.

Tabel 3.

Nilai keterampilan metakognitif siswa SMA berdasarkan gender

\begin{tabular}{lllllll}
\hline & \multicolumn{3}{l}{ Jenis Kelamin } & & & \\
Variabel & Laki-laki & \multicolumn{3}{l}{ Perempuan } \\
& N & M & SD & N & M & SD \\
\hline $\begin{array}{l}\text { Tingkat keterampilan berpikirre flektif } \\
\text { dalam menyelesaikan masalah }\end{array}$ & 160 & 18.42 & 3.26 & 196 & 18.60 & 3.13 \\
$\begin{array}{l}\text { Tingkat keterampilandalam membuat } \\
\text { keputusan }\end{array}$ & 160 & 15.10 & 2.89 & 196 & 15.70 & 2.85 \\
$\begin{array}{l}\text { Keterampilan membuat evaluasi alternatif } \\
\text { Skala keseluruhan }\end{array}$ & 160 & 15.70 & 3.43 & 196 & 15.93 & 3.19 \\
Sumber: Observasi Penulis & 160 & 49.22 & 9.58 & 196 & 50.23 & 9.17 \\
\hline
\end{tabular}

Beragam faktor mempengaruhi proses belajar seseorang baik yang bersifat eksternal seperti lingkungan maupun yang bersifat internal dari dalam diri siswa itu sendiri. Salah satu faktor yang berasal dari dalam adalah keterampilan metakognitif. Keterampilan metakognitif ini dapat ditingkatkan melalui beragam penguatan dan pelatihan. Oleh karena itu pemetaan tingkat keterampilan metakognitif menjadi langkah penting untuk memberikan strategi pelatihan dan penguatan yang tepat dalam rangka meningkatkan keterampilan metakognitif siswa.

Dari hasil penelitian seperti yang telah dipaparkan diatas, tampak bahwa keterampilan metakognitif siswa Sekolah Menengah Atas (SMA) berada pada level tinggi yang terdiri dari aspek keterampilan berpikir reflektif untuk menyelesaikan masalah, keterampilan membuat keputusan, dan keterampilan melakukan evaluasi alternatif. Hasil ini sejalan dengan temuan penelitian Listiana, L., Susilo, H., Suwono., \& Suarsini, E. (2016) bahwa strategi pengajaran yang mengasah 
penalaran telah berkontribusi secara signifikan terhadap peningkatan keterampilan metakognitif siswa. Pembelajaran yang memberikan pengalaman metakognitif kepada siswa ini dapat membantu siswa untuk mengatur proses belajar mereka sendiri yang mencakup; (1) pengetahuan tentang diri sendiri, (2) pengetahuan dalam menjalankan tugas, dan (3) pengetahuan dalam strategi belajar, Flavel (1979). Ketiganya meliputi tentang apa sesungguhnya diketahuinya bisa dalam bentuk pengetahuan deklaratif, pengetahuan prosedural, maupun pengetahuan kondisional ataupun bagaimana seseorang secara efektif dapat mengatur aktivitas kognitifnya yang meliputi kegiatan perencanaan, pemantaun dan evaluasi. (Danial, 2016).

Lebih jauh lagi, temuan penelitian tentang korelasi antara level kelas dengan tingkat keterampilan metakognitif yang terungkap dalam penelitian ini menunjukan bahwa keterampilan metakognitif akan semakin berkembang seiring dengan semakin banyaknya pengalaman metakognitif yang mereka alami. Hal ini sejalan dengan model Piaget (dalam Fitri, 2017) tentang perkembangan intelektual dimana kecerdasan seseorang berkembang sesuai dengan tahapan-tahapan dimana setiap tahapannya saling terkait dan berhubungan dan satu tahapan akan mempengaruhi tahapan berikutnya.

Hal lain yang terungkap dari data seperti yang ditunjukan diatas adalah bahwa siswa laki-laki dan perempuan memiliki tingkat keterampilan metakognitif yang sama. Hasil ini sejalan dengan hasil penelitian Sperling et al. (2002), yang menunjukkan bahwa Keterampilan metakognitif pada dasarnya sudah dimiliki pada diri manusia itu sendiri. metakognitif adalah kemampuan seseorang dalam belajar, yang mencakup bagaimana sebaiknya belajar dilakukan, apa yang sudah dan belum diketahui, yang terdiri dari tiga tahapan yaitu perencanaan, pemantauan dan evaluasi.

Metakognisi merupakan kemampuan untuk menyadari, mengetahui, proses kognisi yang terjadi pada diri sendiri dan merupakan kemampuan untuk mengarahkan proses kognisi yang terjadi pada diri sendiri. Sehingga dapat dikatakan bahwa metakogitif berperan dalam membentuk karakter individu. Kemampuan metakognisi siswa SMAN 1 Margaasih Kabupaten Bandung dipandang cukup tinggi, sehingga berpengaruh terhadap proses pembelajaran dan pembentukan karakter siswa. Keterampilan metakognisi ini didasarkan pada dua komponen utama, yakni metakognisi pengetahuan dan metakognisi regulasi. Metakognisi pengetahun berdampak terhadap proses pembelajaran dalam menangkap berbagai konsep dan konstruk pengetahuan. Sementara metakognisi regulasi berdampak kepada kemampuan meregulasi dan membangun karakter disiplin dalam diri siswa. Metakognisi pengetahuan berwujud dalam bentuk prestasi dan hasil belajar, sementara metakognisi regulas berwujud dalam bentuk motivasi dan kedisiplinan. 
Supriatna, E., \& Alawiyah, T

Peningkatan kompetensi dan perubahan perilaku dalam siswa SMAN 1 Margaasih menunjukkan adanya pengaruh langsung dari keterampilan metakognisi yang berkaitan dengan pengalaman. Pengalaman ini didapatkan salah satunya melalui peningkatan level kelas. Sehingga, siswa memiliki kecenderungan yang cukup tinggi dalam proses internalisasi pengetahuan dan menerapkan regulasi diri. Pada dasarnya, hasil penelitian ini hendak menunjukkan kepada kita bagaimana sebuah keterampilan metakognisi memiliki andil besar dalam proses transmisi pengetahuan dan kemampuan adaptasi konsep dan regulasi. Sehingga berdampak kepada motivasi dan prestasi belajar siswa.

\section{PENUTUP}

Keterampilan metakogntif merupakan aspek yang sangat esensial bagi kesuksesan individu dalam proses belajar mereka. Siswa yang memiliki keterampilan metakognitif yang kuat ditandai dengan kemampuan untuk mengatur, memonitor dan mengevaluasi proses berpikir mereka. Keterampilan metakognitif ini semakin berkembang seiring dengan semakin banyaknya pengalaman metakognitif yang dialami oleh siswa. Oleh sebab itu maka strategi pembelajaran yang mengasah penalaran mempunyai kontribusi yang sangat terhadap peningkatan metacognitive skills siswa yang berimplikasi terhadap keberhasilan proses belajar itu sendiri serta hasil pembelajaran yang ingin dicapai. Penelitian serupa disarankan diterus dilakukan dikonteks yang lebih beragam seperti instritusi pendidikan yang berbeda dan kondisi sosio-demografi yang berbeda juga dengan tujuan untuk meningkatkan keterampilan metakognitif siswa.

\section{DAFTAR PUSTAKA}

Budiati, H., Sugiyarto, \& Sarwanto. (2012). Pengaruh Model Pembelajaran POE (Prediction, Observation, And Explanation) Menggunakan Eksperimen Sederhana dan Eksperimen Terkontrol Ditinjau dari Keterampilan Metakognitif dan Gaya Belajar terhadap Keterampilan Proses Sains, Prosiding Seminar Biologi, 9(1).

Coutinbo, S.A. 2007. The relationship between goals, metacognition and academic success. Educate, Vol. 7, No. 1, p. 39-47. http://www.educatejournal.org.

Danial, M. (2016). Kesadaran Metakognisi, Keterampilan Metakognisi dan Penguasaan Konsep Kimia Dasar. Jurnal Ilmu Pendidikan, 17(3), 225-229.

Dunning, D., Johnson, K., Ehrlinger, J., \& Kruger, J. (2003). Why people fail to recognize their own incompetence. Current Directions in Psychological Science, 12(3), 8387. doi: 10.1111/1467-8721.01235.

Dunslosky, J., \& Thiede, K. W. (1998). What makes people study more? An evaluation of factors that affect self-paced study. ActaPsychologica, 98, 37-56.

Everson, H. T., \& Tobias, S. (1998). The ability to estimate knowledge and performance in college: A metacognitive analysis. Instructional Science, 26, 65-79. 
Fitri, R. (2017). Metakognitifpada Proses Belajar Anak dalam Kajian Neurosains. Jurnal Pendidikan (Teori dan Praktik), 2(1), 56-64.

Fitrih, D.M., Ardiana, N., \& Siregar, Y.P. (2018). Analisis Keterampilan Metakognitif ditinjau dari Kemampuan Pemecahan Masalah Siswa Kelas XI MAN Panyabungan, Jurnal MathEdu (Mathematic Education Journal), 1(1).

Flavel, J. (1979). Metacognition and cognitive monitoring: A new area of cognitivedevelopmental inquiry. American Psychologist, Vol. 34, p. 907-11.

Kirkwood, M. (2000). Infusing bigher-order thinking and learning to learn into content instruction: A case study of secondary computing studies in Scotland. Journal of Curriculum Studies, 32, 509-535.

Kusuma, A.S.H.M., \& Nisa, K. (2018). Hubungan Keterampilan Metakognitif dengan Hasil Belajar Mahasiswa S1 PGSD Universitas Mataram pada Pembelajaran Menggunakan Pendekatan Konstruktivisme, Jurnal Ilmiah Profesi pendidikean, 3(2).

Leamnson, R. (1999). Thinking about teaching and learning: developing habits of learning with first year college and university students. Sterling, VA: Stylus.

Listiana, L., Susilo, H., Suwono, H., \& Suarsini, E. (2016). Empowering students" metacognitive skills through new teaching strategy (Group investigation integrated with think talk write in biology classroom, Journal of Baltic Science Education, 15(3), 391-400.

Mustaqim, S.B., Abdurrahman, \& Viyanti. (2013). Pengaruh Keterampilan Metakognitif terhadap Motivasi dan Hasil Belajar melalui Model Problem Based Learning (PBL), Jurnal Pembelajaran Fisika, 5(1).

Ozsoy, G. \& Ataman, A. 2009. The Effect OfMetacognitive Strategy Training On Mathematical Problem Solving Achievement. Internation al Electronic Journal of Elementary Education, 1, 2, 67-82.

Rukminingrum, D. V., Hanurawan, F., Mudiono, A., Universitas, P. D., \& Malang, N. (2017). Pengetahuan Metakognitif Belajar Siswa, (2), 280-284.

Schneider, W. (2008). The development of metacognitive knowledge in children and adolescents: Major Trends and Implications for Education. Mind, Brain and Education, 2(3), 114-121. doi: 10.1111/j.1751-228X.2008.00041.

Schraw, G. (1998). Promoting general metacognitive awareness. Instructional Sciences, 26, 113-125. https://doi.org/10.1023/A:1003044231033.

Schraw, G., Dennison, R.S. 1994. Assessing Metacognitive Awareness. Contemporary Educational Psychology, Vol. 19, p. 460- 475.

Sonowal, M., \& Kalita, M. (2017). A study on metacognitive awareness and academic achievement of higher secondary level students of Di brugarh town of Assam, India. TheClarion: International Multidisciplinary Journal, 6(1), 69-74. https://doi.org/10.5958/2277-937X.2017.00012.0.

Sperling, R. A., Howard, B. C. Miller, L. A., \& Murphy, C. (2002). Measures of 
Supriatna, E., \& Alawiyah, T

children's knowledge and regulation of cognition. Contemporary Educational Psychology, 27, 51-79

Sugiarto, B., Prabowo, \& Suyono (2012). Keterampilan Metakognitif Mahasiswa dalam Menerapkan Teori VSEPR pada Penyelesaian Masalah Bentuk Molekul dan Sudut Ikatan, Jurnal Penelitian Pendidikan Matematika dan Sains, 19(1).

Tuncer, M., \& Kaysi, F. (2013). The Development of Metacognitive Thinking Scale, Turkish Journal of Education (TURJE), 2(4), 44-54. 